MINING

UDC 622.28: 622.831 .3

\author{
V.H. Shapoval ${ }^{1}$, \\ orcid.org/0000-0003-2993-1311, \\ O.V. Solodyankin ${ }^{1}$, \\ orcid.org/0000-0002-0837-6438, \\ O. Ye. Hryhoriev ${ }^{1}$, \\ orcid.org/0000-0002-1121-4720, \\ O. I. Dubovyk ${ }^{1,2}$, \\ orcid.org/0000-0001-6627-7457
}

https://doi.org/10.33271/nvngu/2021-2/017

1 - Dnipro University of Technology, Dnipro, Ukraine, e-mail: alex.solodyankin@gmail.com

2 - State Enterprise "Pervomaiskvuhillia", Hirske, Luhansk Region, Ukraine

\title{
DETERMINING THE PARAMETERS OF A NATURAL ARCH WHILE FORMING SUPPORT LOAD OF A HORIZONTAL ROADWAYS
}

Purpose. Development of a semiempirical method to identify rock pressure on the support of underground mine roadways as well as substantiation of its efficient use area taking into consideration the depth of the mine roadway, its geometry, and hardness of enclosing rocks.

Methodology. Theoretical studies on geomechanical processes taking place in the neighbourhood of roadways using analytical mathematical methods as well as numerical ones. Analysis of the research results and their generalization are involved.

Findings. Methods to identify load (i.e. rock pressure) on the supporting structures have been developed. The methods are based upon the proposed calculation technique for the rock stability coefficient at the boundary of contact between a collapsing arch of the rock (i.e. fall arch) and undisturbed rock mass, i.e. at the boundary of elastic share of peripheral rock mass, and nonelastic one. A stability coefficient has been proposed in the form of projection on vertical axis of forces holding the rock mass, limited by a fall arch, to projection of shear forces.

Originality. For the first time, an analytical and empirical method to identify natural arch over horizontal and vertical mine roadways has been proposed involving their depth, geometry, parameters of rock strength, and its gravity. The abovementioned is the key distinction of the proposed method from the known semiempirical technique by M.M. Protodyakonov to determine natural arch as well as support load.

Practical value. The findings make it possible to predict stability of horizontal mine roadways using mathematical methods. In this context, the depth, geometry, and hardness of enclosing rocks are taken into consideration.

Keywords: roadway, collapsing arch of the rock, rock pressure, rock strength, holding forces, shear forces

Introduction. Progress of the global economy and society inevitably needs further development of underground space both to mine natural resources and construct such subsurface objects as transport tunnels, subway stations and main line tunnels, and so on. Unfortunately, wide range of mining and geological conditions, hydrogeological conditions, and geomechanical ones prevent the development of universal solution for the whole variety of design and process problems.

Rock depth together with its strength is the key parameters determining complexity of construction and operation of subsurface objects as well as nature of peripheral rock mass failure. Rather frequently, scientific sources use such ideas as 'great' mining depth; 'deep' levels [1], and so on. Formation of failure areas along the entire perimeter of a roadway is typical for such conditions; rock failure within the periphery results from compression stresses. Numerous hypotheses consider separately the phenomena being common to the 'great' depths with the formation of large zones of the deformed and disintegrated rocks [2]; decrease in roadway stability [3]; bedrock heaving [4]; dynamic manifestations of rock pressure.

As for the 'small' depths, rock mass failure within the roadway periphery depends upon tension stress with natural arch formation in a roof. Both hypothesis and calculation

(C) Shapoval V. H., Solodyankin O. V., Hryhoriev O. Ye., Dubovyk O. I., 2021 technique to identify arch parameters over a roadway and support pressure by M. Protodyakonov (1907) is the classical solution concerning support selection for such conditions. The hypothesis has generalized simply and conveniently scientific efforts and mining practices accumulated by the time. Moreover, it is still relevant. Numerous governmental and industrywide regulations as for the design of underground objects use the concept of 'natural arch'.

Such a reference document to design roadways in Ukrainian coal mines as 'Development roadways within flat seams. Selection of supports, and protection means and measures: OCU 10.1.00185790.011:2007' provides selection of support parameters in terms of long roadways of coal mines. Empirical coefficients are applied to calculate the height of parabolic collapsing arch of the rock. Gravity within an arch is used to select bearing capacity of the support; density of frames; and roof bolt parameters [5]. Mining depth, being down to $300 \mathrm{~m}$, is considered as a limit to apply the approach application.

Support calculation for such large sectional roadways as installation chambers, and roadheads also involves determination collapsing arch of the rock parameters, i. e. natural arch. (Instruction to compile charts of mining areas, and roadway driving and supporting. 1996). Rock caving area for salvage chambers should take into consideration the influence of a stope approaching the chamber. In this context, arch of the 
disintegrated rocks is identified with the help of numerical modelling techniques using the methods proposed by [6].

Based upon the theory of rock pressure arch by M. M. Protodyakonov, [7] has developed a mechanical model to analyse stability of coal pillars; moreover, equation of seam subsidence has been derived. The proposed theoretical model was in a good agreement with numerical model. The calculation results were supported by actual values of permissible surface subsidence in the process of deposit mining with stowage.

Paper [8] mentions that the theory by M. M. Protodyakonov, using internal friction angle value to characterize rock mass, often produces good outcomes, while describing collapsing rock arch under the conditions of Ostrava-Karvina deposit (the Czech Republic). Parameters of the combined support (i.e. frame-arched support and roof bolting) within the area, influenced by mining operations, have been determined relying upon Protodyakonov hypothesis on the natural arch.

Tunnel design practices involve such determination of parameters of tunnel lining of carrying capacities depending upon gravity within the natural arch as: 2005 ;

CNS 32-04-97 Railway and vehicle tunnels. M.: Russia,

- Indian Standard (Reaffirmed 1995) Code of Practice for Design of Tunnels Conveying Water. Part V. Structural Design of Concrete Lining in Soft Strata and Soils (Second Reprint November, 1990).

Hence, Protodyakonov theory, taking into consideration internal angle of rock friction, span value, and a tunnel height is widely used to design transport tunnels as well as hydraulic ones in the USA, RF, Europe, China, and other countries. As a rule, it is applied for surface soft and loose enclosing rocks as well as for great depth where low-strength rocks occur [9]. Accurate determination of the rock strength coefficient is the key prerequisite for its use.

Numerous studies concern adaptation of Protodyakonov theory of natural arch to the specific conditions of tunnel construction as well as calculation of its structural and technological parameters. Problems of non-standard tunnel construction generate a need for the development of new calculation approaches. In such a way, the current Chinese construction rules and regulations have not any commonly used methods to identify rock pressure for two-arch tunnels. Paper [10] has performed numerical modeling of two-arch tunnel with the help of ANSYS and FLAC3D software packages. In this context, at the initial stage, load was calculated based upon M. M. Protodyakonov theory. Paper [11] proposes analytical method to predict rock pressure on two-arch deep tunnels while modifying M.M. Protodyakonov theory. The results, obtained with the help of the proposed method, are compared with the monitoring data and corrected.

Design of bearing structures of asymmetrical multiarch tunnels has not any reliable methods to evaluate load either. Based upon the assumption on double arch caving of multiarch tunnels as well as upon M. M. Protodyakonov theory, [12] has derived a formula to calculate rock pressure for deep depth. In terms of symmetrical conditions, the derived formula becomes a common mathematical statement for multiarch tunnels supporting correctness of the approach.

Paper [13] has analyzed applicability of different traditional and normative calculation methods for enclosing rock pressure to design parameters of extralarge section tunnel Liantang within eastern express freeway Shēnzhèn (P. R. China). It has been demonstrated that due to large span of Liantang tunnel, corrections are required both for M. Protodyakonov arch theory and design norms of road tunnels. Paper [14] represents the findings concerning rock pressure within a rail tunnel on the basis of M. Protodyakonov arch pressure theory in the process of numerical modeling. The calculation results are compared with normative technique for a railway tunnel design.

To identify load of soft soil of a tunnel support, paper [15] adapts M. M. Protodyakonov theory of soil pressure for differ- ent conditions depending upon the disturbed rock mass state. The obtained results may be applied to calculate parameters of shield mining and the disturbed rock pressure on the tunnel lining.

Specifically the current normative documents and design goals of subsurface objects stipulate topicality of the research.

Literature review. In due time, the calculation technique, based upon the natural arch hypothesis, had substantial progress in the context of rock pressure science. Later, the proposed approach was improved by P. M. Tsymbarevich, V. D. Slesariev, R. Kvapil, and other scientists. M. P. Brodsky was among the first ones who tried to develop a calculation technique for pressure on a support of a vertical shaft on the basis of a hypothesis of natural arch (1933). Substantial disadvantage of the method is that pressure on the support does not depend upon the depth. In the late 1970s, the theory of rock pressure as gravity was developed by E. I. Shemiakin, and others.

Nowadays, a number of papers regard both consideration and improvement of M. M. Protodyakonov hypothesis as for the solving modern scientific and technical problems.

Litvinsky G. G. considers M. M. Protodyakonov hypothesis on the natural arch formation relative to 'shallow' mining depth [16]. The possibility to derive arch from tension stresses within a roadway floor is the element improving M. M. Protodyakonov problem. It is also mentioned that a value of support load is influenced heavily by rock state within the arch of the disintegrated rocks.

Vorobiev A. (2000) determines natural arch height involving rock compression strength. The research objective was to identify optimum ratios between the arch height and roadway width. The findings were used to calculate a support, and stability of rock mass and pillars.

Paper [17] carried out a set of studies and derived dependences of natural arch height according to M. M. Protodyakonov and roadway span value upon the strength and lamination of rocks occurring in a roof.

The author of [18] applies a theory for calculation of bases and slopes to identify load on the supports of roadways. Function of vertical load, derived by the author, is described by means of the second order parabola. The results are compared with the known analogues inclusive of arch hypothesis by M. M. Protodyakonov and P. M. Tsymbarevich.

As paper [19] mentions, reliable prediction of collapsing arch of the rock characteristics is still among the most important and complex problems in the context of tunnel construction. Relying upon a nonlinear Hoek-Brown failure criterion, the paper authors propose analytical solution of the curved failure of rock blocks for deep tunnels. The derived formulas are applicable to predict both height and width of a block, being disintegrated, within the unsupported tunnels making it possible to identify their lining thickness. The model test results as well as analytical solution by M. M. Protodyakonov concerning a natural arch prove out the analytical solution.

Paper [20] analyses the known values and conditions of M. Protodyakonov pressure arch formation using both model and numerical studies; moreover, the paper considers dependences between a span of a tunnel, its depth, and rock mass characteristics. The results, obtained by the authors, helped them identify certain limitations. They believe that the arch pressure theory can be applied if only tunnels are rectangular in shape or they are French type tunnels with stable enclosing rocks and shallow occurrence; a pressure arch is not available within the arch tunnel; a self-stable pressure arch cannot originate in terms of low rock strength and too large tunnel span; the pressure arch and tunnel crashing are impossible if enclosing rocks are stable; and if a tunnel is deep, its crashing will start from both sides so the pressure arch theory cannot be applicable.

Paper [21] contains critical notes relative to the traditional classification as for the depth. The classification relies upon a theory of pressure arch by M. M. Protodyakonov. The authors 
propose their own classification of 'deep' and 'shallow' tunnels based on the failure modes of a periphery rock mass. Moreover, it is noted that the separation of deep tunnels and shallow ones should involve effects of the tunnel design; geological structure; and stability of external rock mass which may stipulate high pressure formation.

Analysis of the research results have shown that despite the fact that M. M. Protodyakonov technique for natural arch and support load determination is widely used to solve practical problems and has demonstrated positive outcomes verified by mining practices, it cannot take into consideration following factors: roadway depth relative to the surface; values of vertical pressure as well as horizontal acting at the rated depth; and rock strength depending upon the stresses at the rated depth.

The paper represents the data of study to avoid the listed disadvantages.

Theoretical research, carried out by M. M. Protodyakonov, is the closest to those performed in the analysis. Consider its solution and the assumptions.

Protodyakonov M. M. formulated the research task as follows. Horizontal long roadway with $2 a$ width rectangular section is located at $H$ depth (Fig. $1, a$ ). It is assumed that a natural equilibrium arch of $b$ height is formed above the roadway.

It is assumed that within its arch, the roadway has experienced complete failure. It has no cohesion while possessing internal friction.

Support erection within the roadway is no bar to natural arch formation. The problem consists of two parts: 1) determination of the arch curve; 2) arch height identification.

The basic assumption is that statically definable threehinged arch is formed within the arch; in addition, the fixed hinges are within points $A, B$, and $O$. The assumption helps define bearing reactions irrespective of the arch section area as well as its elastic, plastic, and other deformation properties.

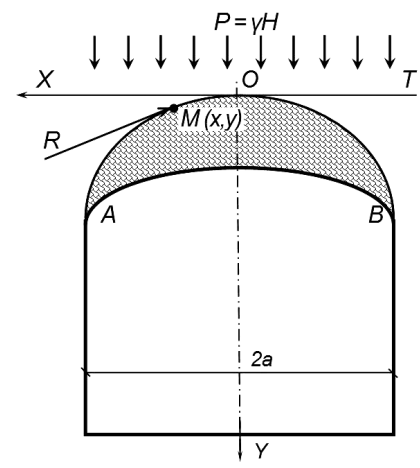

$a$

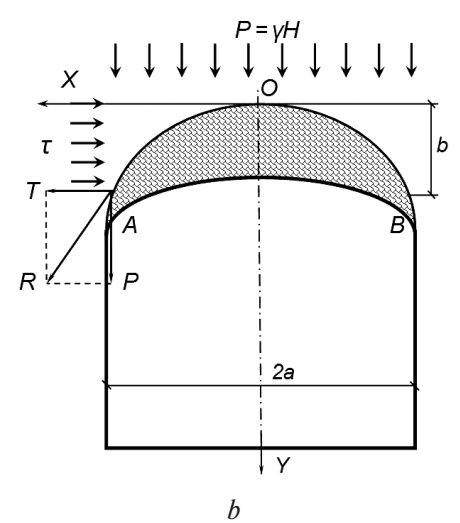

Fig. 1. Scheme for calculating the load on the support according to M.M. Protodyakonov:

$a$ - the problem of defining the shape of the curve; $b$ - the problem of determining the height of the arch
Then, it is required to imbed a reference point in a quoin, and consider $O M$ arch equilibrium (Figs. $1, a, b)$. The rejected $O B$ and $A M$ arch parts should be substituted by reactive forces $T$ and $R$. Since cohesionless environment is considered, $T$ and $R$ are tangential to an equilibrium arch curve.

So, it is necessary to identify the total of moments relative to $M$ point. So,

$$
y=\frac{\partial}{2 \cdot T} \cdot x^{2}=k \cdot x^{2},
$$

where $y$ is ordinate of a curve describing the arch roof; $x$ is abscisse; $k=P /(2 \cdot T) ; p$ is vertical load on the arch (i.e. rock pressure).

Equality (1) is a square parabola equation. Hence, part one of the problem, formulated by M. M. Protodyakonov, has been solved.

To solve part two of the problem, M. M. Protodyakonov proposed to use the following semiempirical formula

$$
\left.b=\frac{a}{f} ; \quad f=\frac{R_{c}}{k_{\tilde{n}}}\right\},
$$

where $b$ is rise; a is half-span of the roadway; $R_{c}$ is rock uniaxial compression strength; $k_{c}$ is empirical coefficient being numerically equal to $10 \mathrm{MPa}$ (it should be of the same dimensionality as rock uniaxial compression strength $R_{c}$ and vice versa).

Involving the known values of an arch fall $a$ and $b$ as well as rock gravity, it is quite easy to identify $Q_{p}$ load per a long meter of a support length

$$
Q_{p}=\frac{4}{3} \cdot \gamma \cdot a \cdot b=\frac{4 \cdot a^{2}}{3 \cdot f} \cdot \gamma .
$$

If interval of frames, bearing load by rock weight, is $l$ then each of the frames resists the following load

$$
Q_{i}=\frac{4}{3} \cdot \gamma \cdot a \cdot b \cdot l=\frac{4 \cdot a^{2}}{3 \cdot f} \cdot \gamma \cdot l .
$$

The abovementioned methods to identify pressure on a support have the following disadvantages:

1. Roadway deepening results in the increased pressure on the peripheral rock mass. In this context, the resulting (2-4), derived by Protodyakonov, involves neither vertical nor horizontal pressure.

2. Strength of rock, housing a roadway, is not taken in full consideration. Let us explain the argument in greater detail.

Complete description of rock strength involves its uniaxial compression strength $R_{c}$ and uniaxial tension strength $R_{p}$. Such strength indices as internal friction angle $\varphi$ and specific cohesion c correspond to the characteristics.

The following relation is available between the listed characteristics

$$
\left.c=\frac{1}{2} \cdot \sqrt{R_{c} \cdot R_{p}} ; \quad \varphi=\arcsin \left[\frac{R_{c}-R_{p}}{R_{c}+R_{p}}\right]\right\} .
$$

Since the solution by M. M. Protodyakonov does not involve rock tension strength (i. e. it is equal to zero), (5) equalities will be

$$
\left.\begin{array}{l}
c=\frac{1}{2} \cdot \sqrt{R_{c} \cdot R_{p}}=\frac{1}{2} \cdot \sqrt{R_{c} \cdot 0}=0 \\
\varphi=\arcsin \left[\frac{R_{c}-R_{p}}{R_{c}+R_{p}}\right]=\arcsin \left[\frac{R_{c}-0}{R_{c}+0}\right]=\frac{\pi}{2}
\end{array}\right\} .
$$

It follows from (6) that M. M. Protodyakonov considers absolutely loose ground where internal friction angle is $\varphi=$ $=\pi / 2$. The assumption is not reasonable. The matter is that internal friction angle of rock cannot exceed significantly $\varphi=$ $=\pi / 4$ value. 
The stated makes it possible to conclude that despite its importance and popularity, the approach to identify both roof arch and support load, proposed by M. M. Protodyakonov, needs substantial improvement and consideration of a number of factors.

Purpose. The research objective is the development of a semiempirical method to determine rock pressure on the roadways support and substantiate its rational application area taking into consideration the roadway depth, its geometry, and strength of enclosing rocks.

Statement of the basic material of the research. The research problem was formulated as follows.

1. Walls of roadway are within much harder rock to compare with its roof (Fig. 2)

2. Periphery form of rock inrush over a roadway is known (more precisely, its equation $Y(x)$ ).

3. Shear is the rock failure mechanism. Hence, its behaviour in the process corresponds to Mohr-Coulomb strength condition.

4. Strength characteristics of the rock are known (i.e. specific cohesion $c$; internal friction angle $\varphi$ or uniaxial compression strength $R_{c}$; uniaxial tension strength $R_{p}$ ).

5. Gravity of soil (rock) $\gamma$ is known.

6. Horizontal pressure as well as vertical one at the rated depth is known.

It is required to:

1. Evaluate the arch over the roadway as well as its stability degree.

2. Identify the rock pressure on the supporting structure.

3. Derive the equation of a curve describing boundary of inrush arch.

4. Define the boundary separating disintegrated rocks and undisturbed ones within the roadway roof (Fig. 3).

5. Determine the support load using the known parameters of inrush periphery, rock volume, and gravity.

To evaluate the roadway roof, rock pressure on the supporting structure, and equation of the curve describing a boundary of inrush arch, let us make the following assumptions.

1. Rock strength is subject to Coulomb-Mohr law [22]

$$
\tau=\sigma \cdot \operatorname{tg}(\varphi)+c=\frac{\sigma}{2} \cdot \frac{R_{\partial}-R}{\sqrt{R_{\partial} \cdot R}}+\frac{1}{2} \cdot \sqrt{R_{\partial} \cdot R} .
$$

2. At a first approximation, the equation inrush arch boundary may be represented in the form of a square parabola

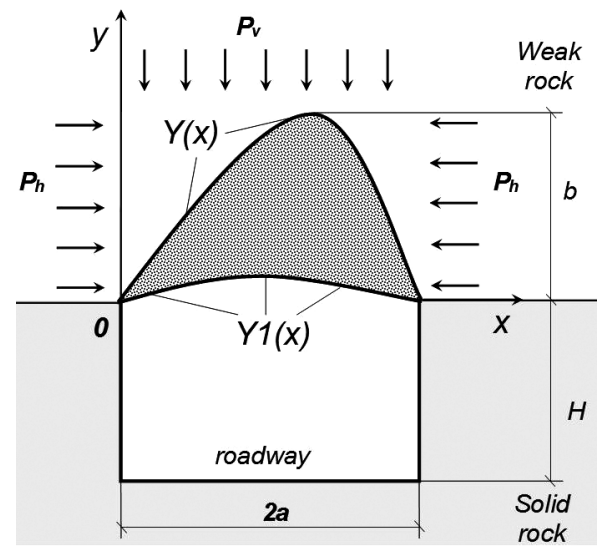

Fig. 2. Scheme to calculate periphery form of rock failure over a horizontal roadway:

$P_{v}$ - vertical pressure; $P_{h}$ - horizontal pressure; $Y(x)$ - equation of upper boundary of the disintegrated rock; $Y_{1}(x)$ - equation of lower boundary of the disintegrated rock; $b$ - ordinate of the upper point of the disintegrated rock; $a$ - half-width of the roadway span; $x$ and $y$-coordinates

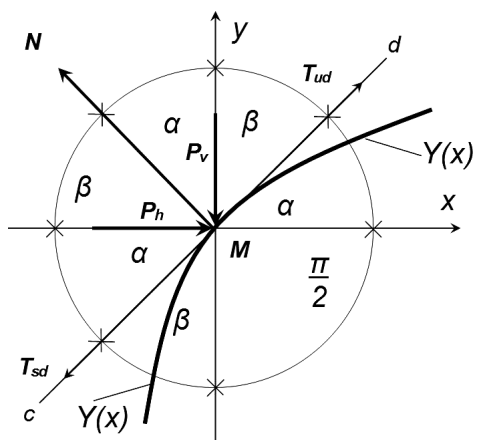

Fig. 3. Scheme to determine shearing and holding forces:

$Y(x)$ - equation of inrush arch boundary; $x$ and $y$-current coordinates; $c-d$ - tangent to $Y(x)$ curve within $M$ point $\alpha-$ slope angle of the tangent to $X$-axis; $\beta=\pi / 2-\alpha-$ slope angle of the tangent to $Y$-axis; $P_{v}$, and $P_{h}-$ vertical and horizontal rock pressure components acting within the limits of a meter of the roadway length $\left(\mathrm{kN} / \mathrm{m}^{2}\right) ; T_{\text {sd }}$ and $T_{u d}$ are - shearing load and holding load directed along the tangent to the M point

$$
Y(x)=\frac{b}{a^{2}} \cdot x \cdot(2 \cdot a-x) .
$$

3. Depending upon the inclination angle of rock seams (layers), failure roof may be of an irregular form as it is shown in Fig. 2. The research considers a case for symmetrical inrush form (in terms of horizontal occurrence of rock layers).

Further, we consider holding forces and shearing forces acting within some point $M$ (Fig. 3)

Since shear is the reason for the rock disintegration, the holding forces as well as shearing ones are tangential to $Y(x)$ curve within point $M$ (Fig. 3).

It should also be taken into consideration that

$$
\beta=\frac{\pi}{2}-\alpha,
$$

as it follows from the scheme in Fig. 3.

Determine differentials of forces acting at point $M$. For the purpose, we consider infinitesimal virtual increments of $\mathrm{dx}$ abscissa, dy ordinate, and ds arch (Figs. 3 and 4). So,

$$
\left.\begin{array}{l}
\operatorname{tg}(\alpha)=\frac{d Y(x)}{d x} ; \quad \alpha=\operatorname{arctg}\left[\frac{d Y(x)}{d x}\right] \\
d y=d x \cdot \operatorname{tg}(\alpha) ; \quad d s=\sqrt{d^{2} x+d^{2} y}=\frac{d x}{\cos (\alpha)}
\end{array}\right\} .
$$

Then, determine differential of shearing and holding forces. Shearing force differential $d T_{s d}$ is

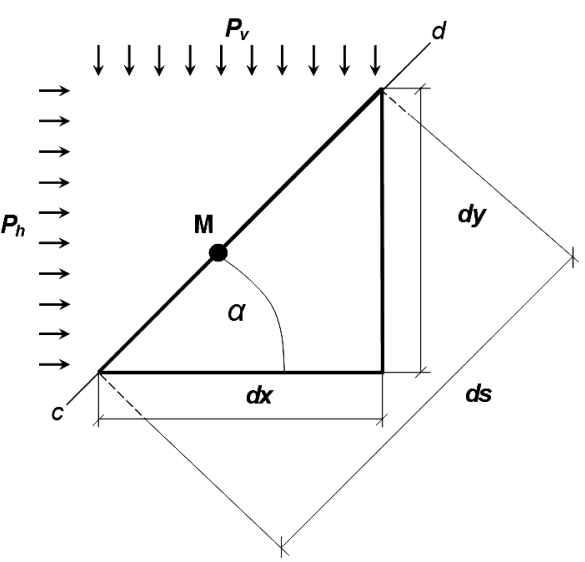

Fig. 4. Scheme to determine differentials of shearing and holding forces. The Figure should be analysed together with Fig. 3 


$$
d T_{s d}=P_{v} \cdot \cos (\beta) \cdot d x=P_{v} \cdot \sin (\alpha) \cdot d x .
$$

Normal force differential $\mathrm{dN}$ is

$$
\begin{aligned}
d N & =P_{v} \cdot d x \cdot \cos (\alpha)+P_{h} \cdot d y \cdot \cos (\beta)= \\
& =\frac{P_{v} \cdot \cos ^{2}(\alpha)+P_{h} \cdot \sin ^{2}(\alpha)}{\cos (\alpha)} \cdot d x .
\end{aligned}
$$

Holding force differential $d T_{u d}$ is

$$
\begin{aligned}
d T_{u d}= & d N \cdot \operatorname{tg}(\varphi)+c \cdot d s+P_{h} \cdot d y \cdot \cos (\alpha)=P_{v} \cdot \operatorname{tg}(\varphi) \cdot \cos (\alpha)+ \\
& +P_{h} \cdot \operatorname{tg}(\alpha) \cdot[\cos (\alpha)+\sin (\alpha) \cdot \operatorname{tg}(\varphi)]+\frac{c}{\cos (\alpha)} .
\end{aligned}
$$

So, let us identify the projections of both holding and shearing forces on a vertical axis.

Shearing force projection on a vertical $T_{s d, y}$ axis is

$$
\begin{gathered}
T_{s d, y}=\int_{0}^{2 \cdot a} d T_{s d} \cdot \cos (\beta)+Q_{v}= \\
=\int_{0}^{2 \cdot a} P_{v} \cdot \sin (\alpha) \cdot d x+\gamma \cdot \int_{0}^{2 \cdot a}\left[Y(x)-Y_{1}(x)\right] \cdot d x .
\end{gathered}
$$

In this context, $Q_{v}$ is weight of rock within the inrush arch; and $\gamma$ is its gravity.

Holding force projection on a vertical $T_{u d, y}$ axis is

$$
\begin{gathered}
T_{u d, y}=\int_{0}^{2 \cdot a} d T_{u d} \cdot \cos (\beta)= \\
=\int_{0}^{2 \cdot a} P_{h} \cdot \sin ^{2}(\alpha) \cdot[1+\operatorname{tg}(\alpha) \cdot \operatorname{tg}(\varphi)] \cdot d x+ \\
+\int_{0}^{2 \cdot a}\left[P_{v} \cdot \operatorname{tg}(\varphi) \cdot \sin (\alpha) \cdot \cos (\alpha)+c \cdot \operatorname{tg}(\alpha)\right] \cdot d x .
\end{gathered}
$$

(8) and (9) equalities help evaluate the roof strength while introducing a stability coefficient in the form of ratio between the projection of holding forces on a vertical axis and projection of shearing forces on the axis

$$
k_{u}=\frac{T_{u d, y}}{T_{s d, y}} .
$$

Such an approach simplifies determination of a roof state over the roadway (i.e. it is stable, indifferent, or unstable).

Hence, if the roof is stable, then $k_{u}=\frac{T_{u d, y}}{T_{s d, y}}>1$.

If the roof is indifferent, then $k_{u}=\frac{T_{u d, y}}{T_{s d, y}}=1$.

Finally, if the roof is unstable, then $k_{u}=\frac{T_{u d, y}}{T_{s d, y}}<1$.

It follows from (8-10) equalities that when different $b$ values of inrush rise are given, different values of stability coefficient $k_{u}$ are obtained. However, such $b$ values of inrush rise are of interest in terms of which a stability coefficient value is minimum one. In this case, rise should be more than $Y_{1}(x)$ (otherwise, inrush arch will be in the roadway), and less than the depth of an upper point of inrush arch relative to the surface (otherwise, the inrush arch will be beyond the surface).

From the mathematical viewpoint, the arguments formulate a problem to identify minimum of some functional, if several restrictions are met.

Consequently, in terms of the case, formalization of the problem to determine minimum value of the stability coefficient is as follows

$$
\left.\begin{array}{c}
k_{u}=\frac{T_{u d, y}}{T_{s d, y}} \rightarrow \min _{b} \\
Y_{1}(x)<Y(x) \\
x \in(0,2 \cdot a) \\
y \in\left(0, H_{z}\right) \\
b \leq H_{z}
\end{array}\right\}
$$

where $H_{z}$ is distance from the surface to the roadway roof.

To make further statement of the material more convenient, we reduce our (7-11) solutions of (5) problem to one equation system. We have

$$
\left.\begin{array}{c}
k_{u}=\frac{T_{u d, y}}{T_{s d, y}} \rightarrow \min _{b} \\
Q_{p}=\int_{0}^{2 \cdot a} \gamma(x) \cdot\left[Y(x)-Y_{1}(x)\right] \cdot d x \\
\int_{0}^{2 \cdot a} x \cdot \gamma(x) \cdot\left[Y(x)-Y_{1}(x)\right] \cdot d x \\
T_{u d, y}=\int_{0}^{2 \cdot a} P_{h} \cdot \sin { }^{2}(\alpha) \cdot[1+\operatorname{tg}(\alpha) \cdot \operatorname{tg}(\varphi)] \cdot d x+ \\
+\int_{0}^{2 \cdot a}\left[P_{v} \cdot \operatorname{tg}(\varphi) \cdot \sin (\alpha) \cdot \cos (\alpha)+c \cdot \operatorname{tg}(\alpha)\right] \cdot d x \\
T_{s d, y}=\int_{0}^{2 \cdot a} P_{v} \cdot \sin (\alpha) \cdot d x+\gamma \cdot \int_{0}^{2 \cdot a}\left[Y(x)-Y_{1}(x)\right] \cdot d x \\
c=\frac{1}{2} \cdot \sqrt{R_{c} \cdot R_{p}} ; \quad \varphi=\arcsin \left[\frac{R_{c}-R_{p}}{R_{c}+R_{p}}\right] \\
\alpha=\operatorname{arctg}\left[\frac{d Y(x)]}{d x}\right] ; \quad Y_{1}(x)<Y(x) \\
x \in(0,2 \cdot a) ; \quad y \in\left(0, H_{z}\right) ; \quad b \leq H_{z}
\end{array}\right\}
$$

where $k_{u}$ is the stability coefficient; $Q_{p}$ is vertical linear load on a support falling at a meter of the roadway length (its dimensionality is $\mathrm{kN} / \mathrm{m}$ ); $e$ is its application eccentricity (it should be measured relative of the left upper angle of the roadway towards $O X$ axis); $T_{u d, y}$ is projection of holding forces on the ordinate axis; $T_{s d, y}$ is projection of shearing forces on the ordinate axis; $P_{v}$ is a vertical component of rock pressure at the rated depth; $P_{h}$ is a horizontal component of rock pressure at the rated depth; $Y(x)$ is an equation describing upper part of the inrush arch periphery; $Y_{1}(x)$ is an equation describing upper part of the roadway periphery; $b$ is inrush rise; $a$ is half of a roadway span, $H_{z}$ is the distance from the surface to abscissa axis; $\varphi$ is an angle of internal rock friction; $c$ is specific cohesion of rock; $\gamma$ is rock gravity; $R_{c}$ is rock uniaxial compression strength; $R_{p}$ is rock uniaxial tension strength.

Analysis of (12) ratio helped conclude the following: if the horizontal component of rock pressure $P_{h}$ is taken into consideration, then higher values of holding force $T_{u d, y}$ result in the overestimated values of the stability coefficient $k_{u}$ to compare with the values obtained when $P_{h}=0$.

Moreover, the closer $Y_{1}(x)$ function, describing roof surface of the roadway, is to 0 , the greater a shearing force will be.

In other words, the most disadvantageous case is when $P_{h}=0$ and $Y_{1}(x)=0$. In this connection, the problem analysis is of certain interest for engineering evaluations, if our assumptions are taken into consideration. So, we have 


$$
\left.\begin{array}{c}
k_{u}=\frac{T_{u d, y}}{T_{s d, y}} \rightarrow \min _{b} \\
Q_{p}=\int_{0}^{2 \cdot a} \gamma(x) \cdot Y(x) \cdot d x \\
e=\frac{\int_{0}^{2 \cdot a} x \cdot \gamma(x) \cdot Y(x) \cdot d x}{\int_{0}^{2 \cdot a} \gamma(x) \cdot Y(x) \cdot d x} \\
T_{u d, y=}=\int_{0}^{2 \cdot a}\left[P_{v} \cdot \operatorname{tg}(\varphi) \cdot \sin (\alpha) \cdot \cos (\alpha)+c \cdot \operatorname{tg}(\alpha)\right] \cdot d x \\
T_{s d, y}=\int_{0}^{2 \cdot a}\left[P_{v} \cdot \sin (\alpha)+\gamma \cdot Y(x)\right] \cdot d x \\
c=\frac{1}{2} \cdot \sqrt{R_{c} \cdot R_{p}} ; \quad \varphi=\arcsin \left[\frac{R_{c}-R_{p}}{R_{c}+R_{p}}\right] \\
\alpha=\operatorname{arctg}\left[\frac{d Y(x)}{d x}\right] \\
Y(x)>0 \\
x \in(0,2 \cdot a) \\
y \in\left(0, H_{z}\right) \\
b \leq H_{z}
\end{array}\right\}
$$

In terms of the idea that inrush arch is symmetrical relative to a vertical straight $y=a$, passing through the centre of a roadway span, ratio system (13) will take on a simpler form

$$
\begin{aligned}
& k_{u}=\frac{T_{u d, y}}{T_{s d, y}} \rightarrow \min _{b} \\
& Q_{p}=\int_{0}^{2 \cdot a} \gamma(x) \cdot Y(x) \cdot d x \\
& e=\frac{\int_{0}^{2 \cdot a} x \cdot \gamma(x) \cdot Y(x) \cdot d x}{\int_{0}^{2 \cdot a} \gamma(x) \cdot Y(x) \cdot d x} \\
& \left.T_{u d, y}=\int_{0}^{a}\left[P_{v} \cdot \operatorname{tg}(\varphi) \cdot \sin (\alpha) \cdot \cos (\alpha)+c \cdot \operatorname{tg}(\alpha)\right] \cdot d x\right) \\
& T_{s d, y}=\int_{0}^{a}\left[P_{v} \cdot \sin (\alpha)+\gamma \cdot Y(x)\right] \cdot d x \\
& \tilde{n}=\frac{1}{2} \cdot \sqrt{R_{\tilde{\partial}} \cdot R} ; \quad \varphi=\arcsin \left[\frac{R_{\tilde{\delta}}-R}{R_{\tilde{\delta}}+R}\right] \\
& \alpha=\operatorname{arctg}\left[\frac{d Y(x)}{d x}\right] \\
& Y(x)>0 \\
& x \in(0, a) \\
& y \in\left(0, H_{z}\right) \\
& b \leq H_{z}
\end{aligned}
$$

In the process of the numerical experiment, we applied (14) ratios for 50, 100, 500, $1000 \mathrm{~m}$ depth roadways with $2 \cdot a=$ $=3.0$ span width to calculate the values of the stability coefficient $k_{u}$, and $b$ rise.

Equation of inrush arch was assumed as follows

$$
Y(x)=b \cdot \frac{4}{9} \cdot x \cdot(3-x)
$$

In this case, $\alpha(x)$ angle is

$$
\alpha(x)=\operatorname{arctg}\left[b \cdot\left(4-\frac{8}{3} \cdot x\right)\right] .
$$

Similar calculations were performed using the classical theory by M. M. Protodyakonov. In this case, inrush rise was determined using (2) formulas; the stability coefficient was identified with the help of the following formulas

$$
\left.\begin{array}{c}
T_{u d, y}=\int_{0}^{a}\left[P_{v} \cdot \operatorname{tg}(\varphi) \cdot \sin (\alpha) \cdot \cos (\alpha)+c \cdot \operatorname{tg}(\alpha)\right] \cdot d x \\
T_{s d, y}=\int_{0}^{a}\left[P_{v} \cdot \sin (\alpha)+\gamma \cdot Y(x)\right] \cdot d x \\
k_{u}=\frac{T_{u d, y}}{T_{s d, y}} \\
\tilde{n}=\frac{1}{2} \cdot \sqrt{R_{\delta} \cdot R} \\
\varphi=\arcsin \left[\frac{R_{\delta}-R}{R_{\partial}+R}\right] \\
\left.\begin{array}{c}
\alpha=\operatorname{arctg}\left[\frac{d Y(x)}{d x}\right] \\
Y(x)>0 \\
x \in(0, a) \\
y \in\left(0, H_{z}\right) \\
b \leq H_{z}
\end{array}\right\} . \\
w
\end{array}\right\}
$$

For the calculations, we applied such initial data as:

- rock gravity being $\gamma=20 \mathrm{kN} / \mathrm{m}^{3}$;

- rock compression strength being $R_{c}=10 \mathrm{MPa}=10000 \mathrm{kPa}=$ $=1000 \mathrm{t} / \mathrm{m}^{2}=100 \mathrm{~kg} / \mathrm{cm}^{2}$;

- rock tension strength being $R_{r}=1.85 \mathrm{MPa}=1850 \mathrm{kPa}=$ $=185 \mathrm{t} / \mathrm{m}^{2}=18.5 \mathrm{~kg} / \mathrm{cm}^{2}$.

The listed strength characteristics are typical for such sedimentary rocks as aleurite, argillite, marl, chalk, and soft limestone.

The calculation results are summarized in the Table.

Figs. 5 and 6 demonstrate graphic representation of some calculation results.

Analysis of the data represented in the Table and in the Figures made it possible to conclude the following.

1. The values of inrush arch rise over a roadway, identified by means of M.M.Protodyakonov theory, cannot depend upon the roadway depth; they have a constant value. In this context, clear tendency of the increase arch rise over a roadway along with its deepening takes place.

Table

The results concerning determination of rock stability coefficient, inrush arch over a roadway with rectangular section, and support load

\begin{tabular}{|c|c|c|c|c|c|c|}
\hline \multirow{2}{*}{$\begin{array}{c}\text { Depth of } \\
\text { the roadway } \\
\text { roof, m }\end{array}$} & \multicolumn{2}{|c|}{$\begin{array}{c}\text { Calculation results involving } \\
\text { M. Protodyakonov theory }\end{array}$} & \multicolumn{3}{|c|}{$\begin{array}{c}\text { Calculation results } \\
\text { involving (14) ratios }\end{array}$} \\
\cline { 2 - 7 } & $b, \mathrm{~m}$ & $k_{u}$, u.f. & $Q_{p}, \mathrm{kN}$ & $b, \mathrm{~m}$ & $k_{u}$, u.f. & $Q_{p}, \mathrm{kN}$ \\
\hline 10 & 1.5 & 21.79 & 60 & 1.4 & 21.77 & 56 \\
\hline 100 & 1.5 & 3.23 & 60 & 1.65 & 3.22 & 66 \\
\hline 500 & 1.5 & 1.33 & 60 & 2.99 & 1.14 & 119.6 \\
\hline 1000 & 1.5 & 1.10 & 60 & 4.24 & 0.79 & - \\
\hline
\end{tabular}

Note: Support load was not identified for $k_{u}<1$ values. That depends on the fact that in this context extra studies on rock mass stability beyond inrush arch should be involved 


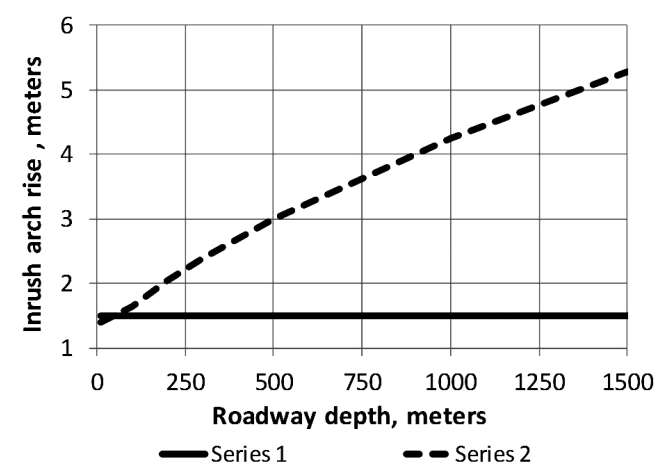

Fig. 5. Dependences of inrush arch rise upon the roadway depth: series 1 shows inrush arch rise calculated with the use of M. M. Protodyakonov theory; series 2 shows inrush arch rise calculated with the use of the developed technique

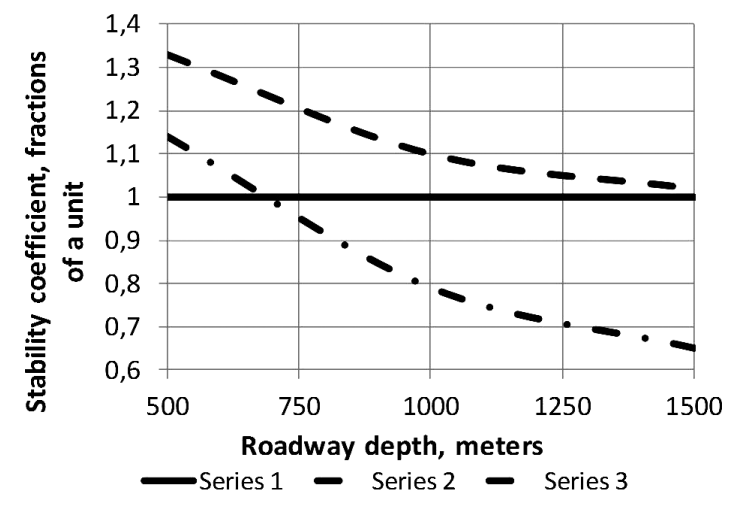

Fig. 6. Dependences of the stability coefficient of inrush arch upon the roadway depth:

series 1 demonstrates the stability coefficient corresponding to indifferent state; series 2 demonstrates the stability coefficient for the case when inrush arch rise was calculated using M. M. Protodyakonov theory; series 3 demonstrates the stability coefficient for the case when inrush arch rise was calculated using the developed technique

Moreover, a roof, calculated with the use of the proposed techniques, is of a shape being close to a circular arch if a roadway is shallow. If a roadway is deep then the shape is almost arrow-like.

2. The values of the rock stability coefficient over a roadway, calculated using the elements of M. M. Protodyakonov theory, decrease along the roadway roof deepening. In addition, within the whole depth range, the values of the stability coefficient are more than a unit. In other words, the roadway roof is stable.

In this context, the values of the rock stability coefficient over a roadway are always less than the comparable ones identified using the elements of M.M. Protodyakonov theory. Moreover, starting from $600 \mathrm{~m}$ depth, the roadway roof will be unstable.

3. Down to a certain roadway depth, values of inrush arch rise over the roadway as well as the rock stability coefficient identified using the techniques, considered by the paper, are almost similar (Figs. 7 and 8).

To analyse the problem, relative errors between the characteristics were calculated. The following formulas were involved:

- to define relative error between the values of arch rise and

$$
\varepsilon_{b}=\left|\frac{b_{i}-b_{a}}{b_{a}}\right| \cdot 100 \% ;
$$

- to define relative error between the values of rock stability coefficient over a roadway

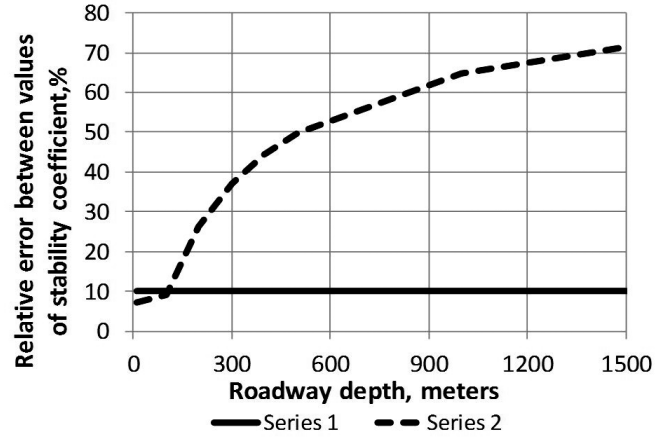

Fig. 7. Dependence of relative error between the arch rise values, calculated with the use of different techniques, upon the roadway depth (series 2). Series 1 is a comparison curve

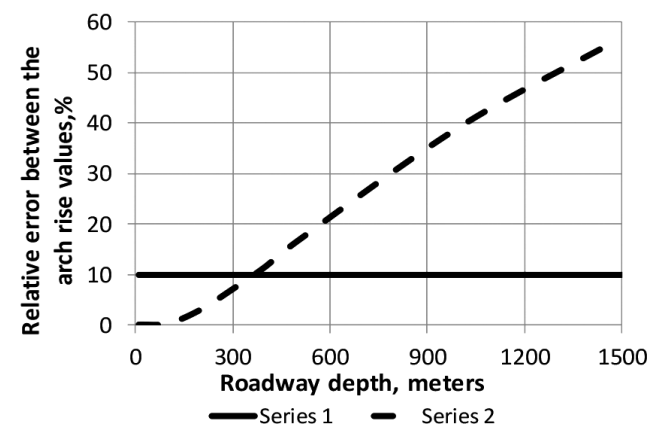

Fig. 8. Dependence of the relative error between values of the stability coefficient, determined with the help different techniques, upon a roadway depth (series 2). Series 1 is a comparison curve

$$
\varepsilon_{k_{u}}=\left|\frac{k_{u},-k_{a}}{k_{u, a}}\right| \cdot 100 \% .
$$

The following notations were used in $(15,16): \varepsilon_{b}$ is relative error between the values, calculated using different techniques for determination of collapsing arch of the rock over a roadway; $\varepsilon_{k u}$ is relative error between the values, calculated using different techniques for determination of the rock stability coefficients; $b_{n}$ is rise identified with the help of M. M. Protodyakonov theory; $b_{a}$ is rise identified using the proposed technique; $k_{u, n}$ is the coefficient of rock stability within a roadway roof calculated using the elements by M. M. Protodyakonov; $k_{u, a}$ is the coefficient of rock stability within a roadway roof defined using the proposed technique.

Fig. 7 represents a dependence of relative error between the values of arch rise upon a roadway depth. The values were identified using different techniques; the dependence was developed using (15).

The dependences represented in Figs. 7 and 8 helped conclude the following:

1. Down to $100 \mathrm{~m}$ roadway depth, the values of inrush arch rise calculated with the help of M. M. Protodyakonov theory and those ones calculated with the help of the proposed techniques are almost similar.

$10 \%$ and larger divergence between the inrush arch rise, identified using different techniques, takes place starting from $120 \mathrm{~m}$ depth.

2. Further deepening results in the monotonous increase in difference between the stability coefficient values determined with the help of methods listed by the paper.

It should be mentioned that the current design standards for roadways of Ukrainian mines also limit application of M. M. Protodyakonov theory within $80-100 \mathrm{~m}$ depth (down to $300 \mathrm{~m}$ according to OCU 10.1.00185790.011:2007). 


\section{Conclusions.}

1. It has been understood that the semiempirical method for identification of rock pressure on the roadways support, proposed by M.M.Protodyakonov, needs its improvement since it prevents involvement of a roadway depth, values of vertical and horizontal pressure, acting at the rated depth, and rock strength dependence upon actual stresses.

2. The stability coefficient $k_{u}$ is introduced to identify collapsing arch of the rock strength. Numerically, the coefficient is equal to the ratio between the forces, holding rock above a roadway, and shearing forces. In this case, if $k_{u}>1$, then rock over a roadway is stable; if $k_{u}=1$, then rock over a roadway is indifferent; if $k_{u}<1$, then rock over a roadway is unstable.

3. The problem to determine minimum value of the roof stability coefficient over a roadway as well as inrush arch rise, corresponding to it, may be reduced to the optimization theory problem.

4. The following was defined while testing the method for determination of pressure on a support:

- values of arch rise over a roadway as well as load on a support depend upon the roadway location, gravity, and rock strength characteristics;

- if a roadway is shallow, then its roof shape is close to a circular line. If a roadway is deep, then the shape is almost archly (i.e. arrow-like);

- values of the rock stability coefficient over a roadway, calculated using the elements of M. M. Protodyakonov theory, decrease along with the roadway deepening. Moreover, within the whole depth range, values of the stability coefficient are more than a unit. In other words, the roadway roof is always stable;

- vertical load on a support, identified using the elements of M. M. Protodyakonov theory, cannot depend on a roadway depth (consequently, upon the rock pressure acting at the depth either). Values of the rock stability coefficient over a roadway, determined with the use of the proposed technique, are less than the analogical ones calculated on the basis of M. M. Protodyakonov theory. In addition, starting from $600 \mathrm{~m}$ depth, the roadway roof will always remain unstable.

5. The results make it possible to predict strength, stability, and bearing capacity of the roof over the horizontal underground roadways as well as identify the pressure on a support.

\section{References.}

1. Solodyankin, A.V., Martovitsky, A.V., \& Smirnov, A.V. (2015). Substantiation of effective solutions of supporting extended workings based on an assessment of geomechanical conditions at "Pavlogradugol" mine. Naukovedenie, 3(7), 1-14. https://doi.org/10.15862/13TVN315.

2. Nazimko, V., \& Zakharova, L. (2017). Cluster behavior of the ground during its irreversible movement. Acta Geodunamica et Geomaterialia, 14(4), 445-462. https://doi.org/10.13168/ AG.2017.0025.

3. Solodyankin, A., Hapieiev, S., Vygodin, M., \& Yanko, V. (2017). Energy efficient technologies to support mine workings under complicated geomechanical conditions. Advanced Engineering Forum, 25, 35-42. https://doi.org/10.4028/www.scientific.net/AEF.25.35.

4. Shashenko, A., Solodyankin, A., \& Gapieiev, S. (2010). Bifurcation model of rock bottom heaving in mine workings, (pp. 71-76). New Techniques and Technologies in Mining. London: CRC Press/Balkema.

5. Grigoriev, O., Tereschuk, R., \& Tokar, L. (2015). Assessment of economic efficiency AMS-A (anchor-meshworkshotcreting) support structure in terms of coal mines. In New Developments in Mining Engineering 2015: Theoretical and Practical Solutions of Mineral Resources Mining, (pp. 85-89). London: Taylor \& Francis Group.
6. Sdvyzhkova, O., Babets, D., Kravchenko, K., \& Smirnov, A. V. (2015). Rock state assessment at initial stage of longwall mining in terms of poor rocks of Western Donbass. In New Developments in Mining Engineering: Theoretical and Practical Solutions of Mineral Resources Mining, (pp. 65-70). London: Taylor \& Francis Group.

7. Yihe, Yu., \& Liqiang, M. (2019). Application of Roadway Backfill Mining in Water-Conservation Coal Mining: A Case Study in Northern Shaanxi, China. MDPI, Sustainability, 11(13), 3719. https://doi.org/10.3390/su11133719.

8. Snuparek, R., \& Konecny, P. (2010). Stability of roadways in coalmines alias rock mechanics in practice. Journal of Rock Mechanics and Geotechnical Engineering, 2(3), 281-288. https://doi.org/10.3724/SP.J.1235.2010.00281.

9. Gao, H., He, P., Chen, Z., \& Li, X. (2019). A Novel Calculation Method of Process Load for Extra-Large Section Tunnels. MDPI, Symmetry, 11, 1228. https://doi.org/10.3390/ sym 11101228 .

10. Li, C., Wang, S., Wang, Y., Cui, F., \& Yang, F. (2016). Skewed Pressure Characteristics of Equivalent Load in Double-Arch Tunnel. Journal of Engineering and Technological Sciences, 48(3), 345-358. https://doi.org/10.5614/j.eng.technol. sci.2016.48.3.8.

11. Pengfei, L., Fan, W., Lifeng, F., Huidong, W., \& Guowei, M. (2019). Analytical scrutiny of loosening pressure on deep twin-tunnels in rock formations. Tunnelling and Underground Space Technology, 83, 373-380. https://doi. org/10.1016/j.tust.2018.10.007.

12. Li, P.-F., Wang, F., Nie, X., \& Zhang, C. P. (2019). Methods for calculating rock pressure of symmetrical multi-arch deep tunnels. Chinese Journal of Geotechnical Engineering. https://doi.org/10.11779/CJGE201609009.

13. Gao, H., He, P., Chen, Z., \& Li, X. (2019). Study on a Surrounding Rock Pressure Calculation Method for SuperLarge Section Highway Tunnels, China. MDPI, Symmetry, 11, 1133. https://doi.org/10.3390/sym11091133.

14. Song, Y. (2016). Calculation of Surrounding Rock Pressure Based on Pressure Arch Theory. $5^{\text {th }}$ International Conference on Advanced Materials and Computer Science (ICAMCS 2016). Atlantis Press. https://doi.org/10.2991/icamcs-16.2016.59.

15. Huang, J., Zhang, Y., Ouyang, X., \& Xu, G. (2019). Lagged settlement in sandy cobble strata and earth pressure on shield tunnel. Mathematical Biosciences and Engineering, 16(6). https://doi.org/10.3934/mbe.2019309.

16. Litvinsky, G. G. (2012). Rock pressure at small and deep of development. Collection of scientific papers DSTU. Alchevsk, 37, 21-28.

17. Wu, X., \& Tu, Z. (2017). Research of the Shape of Pressure Arch in Layered Rock Mass Based on the Protodyakonov's Theory. Advances in Engineering Research, 128. $7^{\text {th }}$ International Conference on Manufacturing Science and Engineering (ICMSE 2017), (pp. 250-255). Atlantis Press. https://doi. org/10.2991/icmse-17.2017.45.

18. Zhabko, A. V. (2012). Calculation of loads on the support of horizontal roadways. Bulletin of the Ural State Mining University, 27-28, 72-77.

19. Zhang, C., Han, K., Fang, Q., \& Zhang, D. (2014). Functional catastrophe analysis of collapse mechanisms for deep tunnels based on the Hoek-Brown failure criterion. Journal of Zhejiang University-SCIENCE A, 15(9), 723-731. https://doi. org/10.1631/jzus.A1400014.

20. Zheng, Y., \& Oui, C. (2016). On the limitations of Protodyakonov's pressure arch theory. Modern Tunnelling Technology, 53(2), 1-8. https://doi.org/10.13807/j.cnki. mtt.2016.02.001.

21. Qiu, C., Zheng, Y., Zhang, Y., Tan, W., \& Zhao, S. (2019). Discussion on Classification Method and Criterion for the Deep-buried and Shallow-buried Rock Tunnels. Modern Tunnelling Technology, 56(1), 14-21.

22. Shapoval, V., Shashenko, O., Hapieiev, S., Khalymendyk, O., \& Andrieiev, V. (2020). Stability assessment of the 
slopes and side-hills with account of the excess pressure in the pore liquid. Mining of Mineral Deposits, 14(1), 91-99. https:// doi.org/10.33271/mining 14.01.091.

\section{Визначення параметрів склепіння природної рівноваги при формуванні навантаження на кріплення горизонтальної виробки}

\section{В. Г. Шаповал ${ }^{1}$, О. В. Солодянкін ${ }^{1}$, О. Е. Григор'єв ${ }^{1}$, О. І. Дубовик $\kappa^{1,2}$}

1 - Національний технічний університет «Дніпровська політехніка», м. Дніпро, Україна, email: alex.solodyankin@ gmail.com

2 - Державне підприємство «Первомайськвугілля», м. Гірське, Луганська обл., Україна

Мета. Розробка напівемпіричного методу визначення гірського тиску на кріплення підземних виробок і обгрунтування області його раціонального використання 3 урахуванням глибини розташування виробки, розмірів виробки й міцності вміщуючих порід.

Методика. Теоретичні дослідження геомеханічних процесів, що протікають в околі гірничих виробок, 3 використанням аналітичних і чисельних математичних методів. Аналіз і узагальнення результатів досліджень.

Результати. Розроблена методика визначення навантаження (гірського тиску) на підтримуючі конструкції кріплень. В іiі основу покладено пропонований метод розрахунку коефіцієнта стійкості гірської породи на межі контакту склепіння обвалення (арки вивалу) і незруйнованого породного масиву, тобто на межі пружної та непружної частини приконтурного породного масиву. Запропоновано коефіцієнт стійкості у вигляді відношення проекції на вертикальну вісь сил, що утримують обмежений склепінням обвалення породний масив, до проекції сил, що зсувають.

Наукова новизна. Уперше запропоновано аналітикоемпіричний метод визначення стійкості склепіння природної рівноваги над горизонтальними й похилими виробками з урахуванням глибини їх закладення, геометричних розмірів, міцнісних властивостей породи та іiі питомої ваги. Це є основною відмінністю пропонованого методу від відомого напівемпіричного методу визначення склепіння природної рівноваги й навантаження на кріплення М. М. Протодьяконова.

Практична значимість. Отримані результати дозволяють 3 використанням математичних методів виконувати прогноз стійкості горизонтальних виробок з урахуванням глибини їх закладення, геометричних розмірів і міцнісних властивостей вміщуючих порід.

Ключові слова: гірнича виробка, склепіння обвалення порід, гірський тиск, міцність порід, сили що утримують, сили що зсувають

\section{Определение параметров свода естественного равновесия \\ при формировании нагрузки на крепь горизонтальной выработки}

\author{
В. Г. Шаповал ${ }^{1}$, А. В. Солодянкин ${ }^{1}$, А. Е. Григорьев ${ }^{1}$, \\ А. И. Дубовик $\kappa^{1,2}$
}

1 - Национальный технический университет «Днепровская политехника», г. Днепр, Украина, email: alex. solodyankin@gmail.com

2 - Государственное предприятие «Первомайскуголь», г. Горное, Луганская обл., Украина

Цель. Разработка полуэмпирического метода определения горного давления на крепь подземных выработок и обоснование области его рационального использования с учетом глубины расположения выработки, размеров выработки и прочности вмещающих пород.

Методика. Теоретические исследования геомеханических процессов, протекающих в окрестности горных выработок с использованием аналитических и численных математических методов. Анализ и обобщение результатов исследований.

Результаты. Разработана методика определения нагрузки (горного давления) на поддерживающие конструкции крепей. В ее основу положен предлагаемый метод расчета коэффициента устойчивости горной породы на границе контакта свода обрушения (арки вывала) и неразрушенного породного массива, то есть на границе упругой и неупругой части приконтурного породного массива. Предложен коэффициент устойчивости в виде отношения проекции на вертикальную ось сил, удерживающих ограниченный сводом обрушения породный массив, к проекции сдвигающих сил.

Научная новизна. Впервые предложен аналитико-эмпирический метод определения устойчивости свода естественного равновесия над горизонтальными и наклонными выработками с учетом глубины их заложения, геометрических размеров, прочностных свойств породы и ее удельного веса. Это является основным отличием предлагаемого метода от известного полуэмпирического метода определения свода естественного равновесия и нагрузки на крепь М. М. Протодьяконова.

Практическая значимость. Полученные результаты позволяют с использованием математических методов выполнять прогноз устойчивости горизонтальных выработок с учетом глубины их заложения, геометрических размеров и прочностных свойств вмещающих пород.

Ключевые слова: горная выработка, свод обрушения пород, горное давление, прочность пород, удерживающие силы, сдвигающие силь

Recommended for publication by A. M. Roenko, Doctor of Technical Sciences. The manuscript was submitted 26.10.20. 